\title{
Reactive Oxygen Species Mediated DNA Damage In Human Lung Alveolar Epithelial (A549) Cells From Exposure To Non-Cytotoxic MFI-Type Zeolite Nanoparticles
}

\author{
Kunal Bhattacharya \\ Technological University Dublin \\ Pratap Naha \\ Technological University Dublin \\ Izabela Naydenova \\ Technological University Dublin, izabela.naydenova@tudublin.ie
}

See next page for additional authors

Follow this and additional works at: https://arrow.tudublin.ie/nanolart

Part of the Cell Biology Commons, and the Toxicology Commons

\section{Recommended Citation}

Bhattacharya, K., Naha, P. C., Naydenova, I., Mintova, S., Byrne, H.J., "Reactive oxygen species mediated DNA damage in human lung alveolar epithelial (A549) cells from exposure to non-cytotoxic MFI-type zeolite nanoparticles."Toxicology Letters, 215, 151-160 (2012). doi:10.1016/j.toxlet.2012.10.007

This Article is brought to you for free and open access by the NanoLab at ARROW@TU Dublin. It has been accepted for inclusion in Articles by an authorized administrator of ARROW@TU Dublin. For more information, please contact arrow.admin@tudublin.ie, aisling.coyne@tudublin.ie,gerard.connolly@tudublin.ie.

Funder: HEA PRTLI Cycle 4 INSPIRE

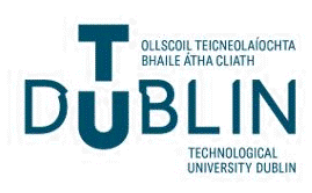


Authors

Kunal Bhattacharya, Pratap Naha, Izabela Naydenova, Svetlana Mintova, and Hugh Byrne

This article is available at ARROW@TU Dublin: https://arrow.tudublin.ie/nanolart/51 
Reactive oxygen species mediated DNA damage in human lung alveolar epithelial (A549) cells from exposure to non-cytotoxic MFI-type zeolite nanoparticles

Kunal Bhattacharya ${ }^{1,2^{*}}$, Pratap C. Naha ${ }^{1,3}$, Izabela Naydenova ${ }^{4}$, Svetlana Mintova ${ }^{5}$, Hugh J Byrne $^{1}$

1. Nanolab, FOCAS Research Institute, Dublin Institute of Technology, Kevin Street, Dublin 8 , Ireland

2. Institute of Environmental Medicine, Division of Molecular Toxicology, Karolinska Institutet, 13 Nobels Väg, S-17177 Stockholm, Sweden

3. Department of Radiology, Perelman School of Medicine, University of Pennsylvania, Philadelphia, PA 19104, USA

4. Centre for Industrial and Engineering Optics, FOCAS Research Institute, Dublin Institute of Technology, Kevin Street, Dublin 8, Ireland

5. Laboratoire Catalyse \&Spectrochimie, Université of Caen, 6, Boulevard du Maréchal Juin, 14050 Caen Cedex, France

\section{Corresponding Author -}

Kunal Bhattacharya,

Nanolab research centre, FOCAS Research Institute, Dublin Institute of Technology,

Kevin Street,

Dublin 8

Ireland

Phone - 00353 (0)1 4027900

Email - kunal.bhattacharya@dit.ie

Now at -

Institute of Environmental Medicine,

Division of Molecular Toxicology

Karolinska Institute,

Nobels Väg 13,

S-17177 Stockholm,

Sweden 


\begin{abstract}
:
Increasing utilization of engineered nanoparticles in the field of electronics and biomedical applications demands an assessment of risk associated with deliberate or accidental exposure. Metal based nanoparticles are potentially most important of all the nanoparticles in terms of health risks. Microporousalumino-silicates and pure silicates named as zeolites and zeo-type materials with variety of structures, chemical compositions, particle sizes and morphologies have a significant number of industrial uses such as in catalysis, sorption and ion-exchange processes. In particular, the nanosized particles due to their unique properties are used in hybrid organic-inorganic materials for photography, photonics, electronics, labeling, imaging, and sensing. The aim of the current study is to investigate pure silica MFI-type zeolitesnanoparticles with sizes of $50 \mathrm{~nm}$ and $100 \mathrm{~nm}$ (samples MFI-50 and MFI-100) under suspended conditions and their toxicological effects on human lung alveolar (A549) cells under in vitro conditions.

Live cell imaging showed that the nanoparticles precipitated from the colloidal suspension of cell culture media as large agglomerates, coming in contact with the cell surface through sedimentation. A cellular proliferative capacity test showed the zeolite nanoparticles to exhibit no significant cytotoxicity belowa concentration of $100 \mu \mathrm{g} / \mathrm{ml}$. However, both the MFI-50 and MFI-100 nanoparticles induced high intracellular reactive oxygen species (ROS) generation and elevated mitochondrial membrane potential in the A549 cells over the measured time period of 12 hours and at concentrations up to $\leq 50 \mu \mathrm{g} / \mathrm{ml}$. DNA fragmentation analysis using the comet assay showed that the MFI-50 and MFI-100 nanoparticles cause genotoxicity in a concentration dependent manner. Furthermore, the rate at which maximum genomic damage was caused by MFI-100 nanoparticles in the A549 cells was found to be high as compared to the MFI-50 nanoparticles. However, the damage caused by the MFI-50 nanoparticles was found to accumulate over a longer period of time as compared to MFI-100 nanoparticles.

The study therefore points towards the capability of the non-cytotoxic zeolite nanoparticles to induce oxidative stress resulting in short-term altered cellular metabolism up-regulation and genomic instability. Although the damage was found to be short-lived, its persistence over longer durations, or stabilization cannot be neglected. Further studies are in progress to yield a better understanding of the mechanisms for oxidative stress and resulting cascade of events leading to genetic damage in the human lung alveolar epithelial cells following exposure to zeolite nanoparticles of different sizes.
\end{abstract}

Key words: Zeolite nanoparticles, Human lung alveolar (A549) cells, Cytotoxicity, Genotoxicity, Reactive Oxygen Species, Mitochondrial Activity 


\section{Introduction:}

The increasing utilization of engineered nanoparticles for a range of application in fields such as electronics, photonics and biomedicine demands an assessment of risk associated with deliberate or accidental exposure. Major health concerns in relation to exposure to nanoparticles arise from the same property which is of great importance for their potential industrial applications, that is, the characteristic of high surface to mass ratio and potentially high surface adhesion and reactivity compared to their larger counterparts (Colvin, 2003; Oberdorster et al., 2005).

Metal based nanoparticles, due to their projected heavy usage in industrial fields, are potentially most important of all the nanoparticles in terms of health risks (Burtea et al., 2008; Huang et al., 2009; Liao et al., 2006; Yang et al., 2008). High rates of induction of lung inflammatory responses and injury following the uptake of these metal based nanoparticles is well documented (Asha Rani et al., 2009; Bhattacharya et al., 2009; Donaldson et al., 2010; Jacobsen et al., 2009; Zhu et al., 2008). Direct and indirect interaction of nanoparticles with cellular systems and induction of oxidative stress has been found capable of inflicting DNA damage through adduct formation, strand breaks and mutations, further leading to cell death or unregulated stimulation of cell growth (cancer)(Hackenberg et al., 2009; Karlsson et al., 2008; Karlsson et al., 2009; Simon-Deckers et al., 2008; Worle-Knirsch et al., 2007). The major cause of concern is long term retention of the non-biodegradable nanoparticles inside the biological system and their distribution following exocytosis (Strano and Jin, 2008).

Silicon dioxide $\left(\mathrm{SiO}_{2}\right)$ particles have been principally implicated in causing silicosisand other pneumological abnormalities in the lungs of occupationally exposed workers (Brown, 2009; Brunner et al., 2006; Jovanovic et al., 2006). The main mode of action of $\mathrm{SiO}_{2}$ particle cytotoxicity and DNA damage following their uptake in cells has been found to be throughthe generation of extra- and intra-cellular reactive oxygen species (ROS) and reduction ofantioxidant levels(De Jong and Borm, 2008). $\mathrm{SiO}_{2}$ nanoparticles have also been found to be more cytotoxic in cells with slow metabolic activity as compared to those with higher metabolic rates at high dosage exposures, causing membrane damages(Chang et al., 2007). Studies done by Elias et al., (Elias et al., 2000) have shown that the biological activity of silica at the cellular level is sensitive to the particle composition and structure of surface functionalities and that the biological response to silica is a surface originated phenomenon. Slowing et al. (Slowing et al., 2009) have shown the toxic (hemolytic) response of the $\mathrm{SiO}_{2}$ to be a surface silanol group dependent effect.

Inorganic nanoparticles, in particular zeolite materials, are being the focus of many researchers due to their diverse framework type structures containing regular channel systems (pores) whose dimension is in the order of the molecular size. Hence, these materials with nanosized dimensions have been considered in wide-ranging applications such as photonics, sensors, electronic and optical detection systems, therapeutics, diagnostics, photovoltaics and catalysis. In addition to the conventional zeolites, the nanosized counterparts with a size in the 
range of 5-1000 $\mathrm{nm}$ have attracted considerable attention during the last two decades (Bein et al., 2005; Mintova, 2003; Valtchev and Mintova, 2011).

While the chemical composition and the framework type structure of zeolites are important, even more vital are the size and shape of the nanoparticles which determine their surface/colloidal properties. The reduction of particle size from micrometer to nanometer scale leads to substantial changes in their properties and thus different performances even in traditional applications are expected. Moreover, the significance of these nanosized materials is mainly related with the emerging area of applications that goes far beyond traditional separation and catalytic processes.(Leite et al., 2010; Majano et al., 2006; Mihailova et al., 2005; Mintova et al., 1999a; Mintova et al., 1999b; Mintova and Valtchev, 2002; Ng et al., 2012).

Zeolite nanoparticles have to date not been studied for their biocompatibility in humans because of relatively low incidences of direct contact. Bedi et al., have studied the biocompatibility of zeolite coated on commercially potent titanium to pluripotent mouse embryonic stem cells and found higher adhesion and rate of cellular proliferation (Bedi et al., 2009). However, since different cells demonstrate different types and magnitude of responses on exposure to nanoparticles, it is important to analyse the response of human lung cells on exposure to the zeolite, as a model of respiratory exposure (Bhattacharya et al., 2009).

The aim of the current study is to explore the properties of crystalline zeolite nanoparticles and their toxicological effects on human lung alveolar (A549) cells under in vitro conditions. The properties of the nanoparticles (pure silica MFI-type zeolite) are studied when suspended in protein/ionic solution using various analytical techniques. The biocompatibility of the nanoparticles is studied by analyzing their effect on the biological properties of cellular proliferation, cytotoxicity and both extracellular and intracellular free radical generation capacity. 


\section{Materials and methods}

\subsection{Test materials and reagents}

Pure silica zeolite nanoparticles with MFI type structure of nominal sizes of $50 \mathrm{~nm}$ and 100 $\mathrm{nm}$ were synthesized according to the procedures described elsewhere (Mintova and Bein, 2001; Mintova et al., 2002; Mintova and Valtchev, 2002). For clarity, the samples with particle size of $50 \mathrm{~nm}$ and $100 \mathrm{~nm}$ will be named as MFI-50 and MFI-100, respectively in the text.

\subsection{Scanning Electron Microscopy (SEM) images}

Suspensions of one microgram per millilitre of MFI-50 and MFI-100 nanoparticles in double distilled water were drop cast onto a Teflon coated carbon tab and dried in an oven at $60^{\circ} \mathrm{C}$ overnight. The carbon tab was mounted onto a steel pin and imaged under high vacuum with an SU6600 SEM microscope.

\subsection{Nitrogen sorption (porosity), zeta potential (ZP) and particle size distribution (PSD)} measurements

$\mathrm{N}_{2}$ sorption measurements(Brunauer et al., 1938) of dry samples were performed using a Gemini series surfacearea analyzer (Micromeritics, USA). Prior to the measurements, approximately $0.05 \mathrm{~g}$ of each sample was degassed at $200{ }^{\circ} \mathrm{C}$ fortwo hours.

Zeta Potential (ZP) and Particle Size Distribution (PSD) measurements of the MFI-50 and MFI-100 nanoparticles were performed using a Malvern-ZS seriesnanozetasizer. Nanoparticles of equal concentration $(100 \mu \mathrm{g} / \mathrm{ml})$ were suspended freshly in deionized double distilled water $\left(\mathrm{ddH}_{2} \mathrm{O}\right)$ and RPMI-1640 medium supplemented with 5\% foetal bovine serum. All the suspensions were evenly mixed with the help of an ultrasonic bath at $50 \%$ power for 5 minutes (mins). The measurements were performed immediately at an ambient temperature of $25^{\circ} \mathrm{C}$ using the Smoluchowski model for zeta potential analysis (Smoluchowski, 1921), and dynamic light scattering (DLS) for particle size distribution.

\subsection{Surface reactivity of zeolite nanoparticles}

The ability of the zeolite nanoparticles to convert hydrogen peroxide into hydroxyl radicals on their reactive surface was analyzed using the Europium(III)-Tetracycline (Eu(III)Tc) derived fluorescence method (Dehaen et al., 2009). For the assay, 4Morpholinepropanesulfonic acid sodium salt (Mops) buffer at a concentration of $10 \mathrm{mM}$ was prepared. In the Mops buffer, different solutions of Europium Tetrachloride of $6.3 \mathrm{mM}$ concentration (solution A) and Tetracycline Hydrochloride at a concentration of $2.1 \mathrm{mM}$ (solution B) were prepared. Both the solutions A and B were mixed in a ratio of 1:1 to form Europium Tetracycline just before the experiment. A $5 \mathrm{mM}$ concentration of hydrogen peroxide $\left(\mathrm{H}_{2} \mathrm{O}_{2}\right)$ was prepared in the Mops buffer. The assay was carried out using a Tecan fluorescent plate reader with an excitation wavelength of $405 \mathrm{~nm}$ and emission wavelength of $620 \mathrm{~nm}$. Measurements were obtained at the different post-exposure time periods of 45, 60 and 75 mins. Increase/decrease in the fluorescence (expressed as percentage of control) was 
calculated by comparing the fluorescence of $\mathrm{Eu}(\mathrm{III}) \mathrm{Tc}$ with $\mathrm{H}_{2} \mathrm{O}_{2}$ (with/without nanoparticles / $\mathrm{FeSO}_{4}$ ) to fluorescence from $\mathrm{Eu}(\mathrm{III}) \mathrm{Tc}$ with no $\mathrm{H}_{2} \mathrm{O}_{2}$. Surface reactivity of the nanoparticles was determined by comparing the rate of dissociation of $\mathrm{H}_{2} \mathrm{O}_{2}$ into hydroxyl radicals following their exposure to the different concentrations of the zeolite MFI-50 and MFI-100 nanoparticles, relative to the natural rate of dissociation of $\mathrm{H}_{2} \mathrm{O}_{2}$ (no nanoparticles/negative control) and positive control $\left(\mathrm{FeSO}_{4}\right)$.

\subsection{Cell culture}

Human alveolar basal epithelial adenocarcinoma (A549) cells were purchased from the European Collection of Cell Cultures (ECACC, Cat No.-86012804). The cells were derived from a 58 years old Caucasian male and have a hypotriploid karyotype. The doubling time for the cell was found to be approximately $22 \mathrm{hrs}$. The cells were maintained in RPMI-1640 media supplemented with 10\% FBS and 1\% Penicillin-Streptomycin (PS) and incubated in a standard humidified condition at $37^{\circ} \mathrm{C}$ and $5 \%$ carbon dioxide. Before exposure, the cells were pre-incubated for 24 hours (hrs) in RPMI-1640 media supplemented with 5\% FBS and $1 \%$ PS.

\subsection{Live cell imaging of zeolite nanoparticle uptake}

For the study, $1 \times 10^{5}$ cells were plated in a T-25 cell culture flask and pre-incubated for 24 hrs before exposure to the nanoparticles. All the nanoparticles were suspended immediately before exposure in RPMI-1640 supplemented with 5\% FBS and 1\% PS. The A549 cells were exposed to $5 \mu \mathrm{g} / \mathrm{ml}$ of the MFI-50 and MFI-100 nanoparticles for a time period of $12 \mathrm{hrs}$. As a negative control, only cell culture medium supplemented with 5\% FBS and 1\% PS was used to culture the A549 cells. Microscopic images of the nanoparticle precipitation and uptake by the cells as compared to the negative control were acquired using AxioVision live cell imaging software attached to a Zeiss fluorescent microscope using the bright-field setting and 40x objective lens at time intervals of 5 mins for $12 \mathrm{hrs}$.

\subsection{Cellular Proliferation Assay}

The effect of exposure to the nanoparticles on the cellular proliferation was measured using the alamar blue (AB) assay (Davoren et al., 2007). For the study, 1 x $10^{5}$ cells were plated and pre-incubated in a flat bottom 96 well plate, $24 \mathrm{hrs}$ before exposure to the nanoparticles. All the nanoparticles were suspended and vortexedimmediately before the exposure in RPMI1640 supplemented with 5\% FBS and 1\% PS followed and the A549 cells were exposed to concentrations of the MFI-50 and MFI-100 nanoparticlesranging between $0.0010-100$ $\mu \mathrm{g} / \mathrm{ml}$, while the negative control was given a fresh change of complete cell culture medium for 24 and 48 hrs. The bioassay was carried out according to the previously described methodology (Davoren et al., 2007). Briefly, control media or test exposures were removed; the cells were rinsed with PBS and $100 \mu \mathrm{l}$ of an AB solution $(5 \%[\mathrm{v} / \mathrm{v}])$ prepared in fresh medium (without FBS or supplements) were added to each well. Following 3 hrs incubation, $\mathrm{AB}$ fluorescence was quantified at the respective excitation and emission wavelengths of 540 $\mathrm{nm}$ and $595 \mathrm{~nm}$ in a Tecanmicroplate reader. The mean fluorescence units for the six 
replicate cultures were calculated for each exposure treatment and the mean blank value was subtracted from these.

\subsection{Intracellular reactive oxygen species (ROS) generation}

Intracellular ROS was measured using 5-(and-6)-chloromethyl-2,7dichlorodihydrofluorescein diacetate acetyl ester (CM- $\mathrm{H}_{2}$ DCFDA) dye. In brief, 1 x $10^{5}$ A549 cells were plated per well in black, flat bottom 96 well plates and pre-incubated for $24 \mathrm{hrs}$. The cells were then exposed to nanoparticleconcentrations of 1,10 and $50 \mu \mathrm{g} / \mathrm{ml}$ for different time intervals $(2,4,6,12$ and $24 \mathrm{hrs})$. After the lapse of the exposure time, the cells were washed twice with PBS and they were exposed to $10 \mu \mathrm{M}$ concentration of CM- $\mathrm{H}_{2} \mathrm{DCFDA}$ and incubated for $1 \mathrm{hr}$ at $37^{\circ} \mathrm{C}$ in a $5 \% \mathrm{CO}_{2}$ humidified incubator. After the lapse of the appropriate time period, fluorescence was measured at an excitation wavelength of $488 \mathrm{~nm}$ and an emission wavelength of $530 \mathrm{~nm}$ in a Tecanmultiplate reader and the fluorescence percentage compared to the negative controls (no nanoparticle exposure) was calculated. All experiments were performed thrice in triplicate.

\subsection{Mitochondrial membrane potential measurement using florescence plate reader and confocal study}

For the study, 1 x $10^{5}$ cells were plated on a flat bottom 96 well plate and pre-incubated for 24 hrs before exposure to the nanoparticles. Both the MFI-50 and MFI-100 nanoparticles were suspended immediately before the exposure in RPMI-1640 supplemented with 5\% FBS and $1 \%$ PS and mixed by vortexing. The nanoparticles were exposed to the A549 cells in different concentrations for exposure times of 1, 2, 4, 6, 12, 24 and $48 \mathrm{hrs}$. As a negative control, cells were treated with normal cell culture media and as a positive control, cell culture media containing $25 \mu \mathrm{M}$ of Valinomycine B (Furlong et al., 1998). Post-exposure, the cells were washed thoroughly using lukewarm PBS and exposed to $5 \mu \mathrm{M}$ of Rhodamine-123 dye. The cells were again incubated for 30 mins and then washed with PBS to remove excess dye. Measurements were obtained immediately at excitation and emission wavelengths of 488 and $535 \mathrm{~nm}$ using Tecanmicroplate reader.

\subsection{Genotoxicity analysis}

The study was performed using single cell gel electrophoresis (comet assay) under alkaline conditions. For each measurement, $1 \times 10^{5}$ A549 cells were plated individually in Falcon's T25 flasks and pre-incubated for $24 \mathrm{hrs}$. The cells were exposed to a freshly prepared suspension of MFI-50 and MFI-100 nanoparticles in cell culture medium at the concentrations of $1,10,50$ and $100 \mu \mathrm{g} / \mathrm{ml}$ for $24 \mathrm{hrs}$. After the elapse of the exposure time, the cells were washed, trypsinized and suspended in low melting agarose and cast onto a gel bond film. Following the polymerization of the agarose, the cells were lysed overnight in a freshly prepared and pre-cooled cell lysis buffer. Electrophoresis of the lysed cells was performed at a $\mathrm{pH} 12.7$ for $10 \mathrm{mins}$ (conditions: $300 \mathrm{~mA}, 1.5 \mathrm{~V} / \mathrm{cm}$ at $4^{\circ} \mathrm{C}$ ), following which the agarose was treated with neutralisation solution for 30 mins and dehydrated in absolute $\mathrm{CH}_{3} \mathrm{COOH}$ for $2 \mathrm{~h}$. These agarose gels were dried in darkness overnight at $4{ }^{\circ} \mathrm{C}$ and stained 
with SYBR-Green nucleic acid stain (Invitrogen; Cat. No. S7585). Imaging and analysis were performed on a Leica upright microscope attached with a CCD camera and using 'Comet Assay $V^{\prime}$ software. The value of olive tail moment (OTM), defined as the product of the tail length and the fraction of total DNA in the tail, is calculated according to

OTM $=$ Tail DNA\% x (Mean Tail length - Mean Head length)

(Comet, 2011)

\subsection{Statistical analysis}

All the physicochemical analysis was preformed once in triplicates while the biological parameter experiments were performed thrice in triplicates. Treated versus control data were statistically analyzed for their significance using one way ANOVA followed by a HolmSidak Post-Hoc test. A p-value of $<0.01$ for control versus treated was considered to be significant. 


\section{Results}

\subsection{Physico-chemical characteristics of the nanoparticles}

Under dry conditions, scanning electron microscopy (SEM) images recorded from the MFI50 and MFI-100 samples showedalmost spheroidal shape crystalsof relatively homogeneous size and morphology (Fig. 1). The particle sizes determined by SEM were consistent with theirnominal values. In addition, the microporosity of the two samples as determined by $\mathrm{N}_{2}$ adsorptionwas similar, although the total porosity of the MFI-50 $\left(108.3 \pm 0.4 \mathrm{~m}^{2} / \mathrm{g}\right)$ was twice as high as that of the MFI-100 sample $\left(48.1 \pm 0.2 \mathrm{~m}^{2} / \mathrm{g}\right)$. This was due to the increased mesoporosity in the MFI-50 sample, which can be explained by the high interparticle porosity between the smaller crystallites (the so-called textural porosity is higher). Assuming constant mass and density of particles per gram, the MFI-50 sample would contain 8 times more nanoparticles compared to the MFI-100.

Suspension of equal concentrations of the MFI-50 and MFI-100 nanoparticles in double distilled water showed that both nanoparticles had highly negative zeta potential (MFI-50 nm: $-22.5 \pm 0.5 \mathrm{mV}$; MFI-100: $-42.5 \pm 0.8 \mathrm{mV}$ ) and formed a stable colloidal suspensions with a monomodal particle size distribution (polydispersity index: $\leq 0.1 \pm 0.0$ ) (Table 1 ). The average particle size distribution determined by DLS was found to be consistent with the observations of SEM imaging, although slightly less than the nominal values in both cases.

Suspension of equal concentration of the MFI-50 and MFI-100nanoparticles in the RPMI1640 cell culture media supplemented with $5 \%$ foetal bovine serum (FBS) proteins caused animmediate and significant reduction in their zeta potential (MFI-50: $-13.2 \pm 0.7 \mathrm{mV}$; MFI100: $-12.6 \pm 0.8 \mathrm{mV}$ ) when measured immediately following their suspension. The particle size distribution also indicated the formation of agglomerates with a high polydispersity index $(\leq 0.2 \pm 0.0)$ (Table 1). Changes in the zeta potential and particle size distribution of the nanoparticlesindicated an interaction between their native surface and the surrounding ions and biomolecules of the medium changing their physical properties.

Surface catalytic activity of the zeolite nanoparticles tested through the capacity to breakdown hydrogen peroxide $\left(\mathrm{H}_{2} \mathrm{O}_{2}\right)$ into hydroxyl radicals $\left(\mathrm{OH}^{*}\right)$ showed the nanoparticles to have a non-reactive surface at all the concentrations and time points tested (Figure 2). Hydrogen peroxide in contact with the nanoparticle surface was found to have a rate of dissociation comparable to that of the negative control, $\mathrm{H}_{2} \mathrm{O}_{2}$, without any nanoparticles, and no significant dose or exposure time dependence was observed. The validity of the study was confirmed using ferric sulphate $\left(\mathrm{FeSO}_{4}\right)$ which was used as a positive control and resulted in a higher rate of dissociation of $\mathrm{H}_{2} \mathrm{O}_{2}$ through a Fenton type reaction.

\subsection{Live cell imaging of zeolite nanoparticle uptake}

Time-lapse live cell images showed continuous sedimentation of the protein covered zeolite nanoparticles in the form of large agglomerates (MFI-50: data not shown; MFI-100 nm: Supplement Movie 2) to the bottom of the cell culture flask continuously over a period of 12 hrs. These agglomerated particles were significantly larger than those observed through DLS 
(Table 1), the difference being that DLS was performed immediately following suspension (within 2 minutes) and the live cell microscopic images were acquired over a period of $12 \mathrm{hrs}$ with a time gap of 5 minutes per image. The time lapse images indicate that the majority of the zeolite nanoparticles were taken up by the cells as agglomerates. While uptake of single nanoparticles is possible (Salvati et al., 2011), in our study we could not discern or differentiate the uptake or translocation of single or agglomerated nanoparticles due to the non-fluorescent nature of the nanoparticles and the resolution limit of the bright-field microscope. No difference was found in the cellular chemotactic movement, physiology and proliferative capacity of the A549 cells exposed to the MFI-50 (not shown) and MFI-100 (Supplement data: Movie 2) nanoparticles as compared to the negative control (Supplement data: Movie 1).

\subsection{Cellular Proliferative Capacity}

Following exposure to a wide range of concentrations of MFI-50 and MFI-100 nanoparticles, after the time periods of 24 and $48 \mathrm{hr}$, no loss of cellular proliferative capacity, as measured by the AB assay, was observed in the A549 cells as compared to the negative control (Figure 3). The results therefore indicate that the MFI-50 and MFI-100 nanoparticles were noncytotoxic to the A549 cells over the concentration range of $0.001-100 \mu \mathrm{g} / \mathrm{ml}$. These data are also in agreement with the previously illustrated non-cytotoxic behaviour of the zeolite nanoparticles as observed using the live cell imaging technique (Supplement: Movie 2).

\subsection{Intracellular Reactive Oxygen Species (ROS) generation}

A short-term exposure (2 hr) of the A549 cells to the MFI-50 and MFI-100 nanoparticles were found to initiate the generation of intracellular ROS, although the dose and time dependence appears complex, as shown in the figures 4A, B (the negative control was set at zero ' 0 ' and hence is at the baseline level ( $\mathrm{x}$ axis) of the graph and not visible). At, lower doses $(1 \mu \mathrm{g} / \mathrm{ml})$, both MFI-50 and MFI-100 nanoparticles caused a biphasic generation of intracellular ROS, showing increased levels at 2 and $12 \mathrm{hrs}$ and subsequent reductions at 4 and $24 \mathrm{hrs}$. A similar biphasic response to nanoparticle exposure was previously reported by Mukherjee et al. (Mukherjee et al., 2010), and the intermediate minima were ascribed to quenching of the initial ROS by intracellular antioxidants. Such a biphasic response was not evident at higher doses $(10 \mu \mathrm{g} / \mathrm{ml}$ and $50 \mu \mathrm{g} / \mathrm{ml})$, although this may be because the initial maximum was shifted to shorter time-points. Similarly, no consistent dose dependent generation of ROS was observable across the time points, with the exception of the $4 \mathrm{hr}$ exposures where we expected a high antioxidant activity. It is therefore difficult to quantitatively compare the levels of ROS generation for the two nanoparticle types. Nevertheless, a comparison of the $4 \mathrm{hr}$ and $12 \mathrm{hr}$ levels indicate that there was no significant difference in the ROS generation for the two different nanoparticles, as shown in figures $4 \mathrm{C}$, D. This was consistent with the uptake of large nanoparticles agglomerates which had lost any specific characteristics of the constituent nanoparticles. 


\subsection{Mitochondrial membrane potential}

Exposure of the A549 cells to both the MFI-50 and MFI-100 nanoparticles was found to cause an increase in the mitochondrial membrane potential $(\Delta \Psi \mathrm{m})$ of exposed A549 cells, although again the dose and time dependence appears complex (Figure 5A, B; The negative control was set at zero ' 0 'and hence is at the baseline level (x axis) of the graph and not visible). For both nanoparticle types, at low doses $(1 \mu \mathrm{g} / \mathrm{l})$, a monotonic increase in $\Delta \Psi \mathrm{mto}$ a maximum after $12 \mathrm{hr}$ exposure was observed. Exposure of the A549 cells to the intermediate dosage of $10 \mu \mathrm{g} / 1$ was found to result in a minor difference in $\Delta \Psi \mathrm{m}$ for each nanoparticle type. For A549 cells exposed to the MFI-50 nanoparticles, a monotonic increase was observed, which was more rapid compared to the lower dosage of $1 \mu \mathrm{g} / \mathrm{l}$. In the case of the A549 cells exposed to the MFI-100 nanoparticles, an initial increase until 4 hrswas followed by a decrease at $6 \mathrm{hrs}$ and a subsequent increase, reaching maxima at $12 \mathrm{hrs}$. The highest dosage of $50 \mu \mathrm{g} / \mathrm{l}$, caused significantly elevated $\Delta \Psi$ mvalues in the A549 cells within the observed shortest exposure time of $2 \mathrm{hrs}$, followed by a steady decrease until the maximum exposure time period of $24 \mathrm{hrs}$. Exposure to the Valinomycine B caused a decrease in $\Delta \Psi \mathrm{m}$ that was $<5 \%$ fluorescence percentage as compared to the negative control in the A549 cells (data not shown).

A comparison of the two parameters of intracellular ROS generation and $\Delta \Psi \mathrm{m}$ at the time points of 4 and 12 hrs shows some degree of correlation, as shown in Figure 6 A, B. While, mitochondria is capable of generating intracellular ROS, through the electron transport chain complexes (McLennan and DegliEsposti, 2000), other pathways for ROS generation also exists and are equally capable of affecting the $\Delta \Psi \mathrm{m}$ through intrinsic cell signalling (Mukherjee et al., 2010; Thannickal and Fanburg, 2000). Variation between the pattern of $\Delta \Psi \mathrm{m}$ modification and intracellular ROS levels within the A549 cells was probably due to a time lapse between the response mechanisms, in addition to the complex interaction between the nanoparticles of different sizes and dosages.

\subsection{Genotoxicity (DNA fragmentation study using Comet assay)}

Analysis of the genotoxicity of the MFI-50 and MFI-100 nanoparticles in the A549 cells was performed by studying the level of DNA fragmentation using the comet assay analysis (parameter: Olive tail moment). The results indicated the occurrence of a statistically significant degree of DNA damage, compared to the negative control, in the A549 cells exposed to the zeolite nanoparticles at all the time points measured (Figure 7; The negative control was set at zero ' 0 'and hence is at the baseline level (x axis) of the graph and not visible). MFI-100 nanoparticle exposure resulted in a higher rate of DNA damage in the A549 cells, reaching maximum DNA damage at $24 \mathrm{hrs}$, as compared to the MFI-50 particles which caused maximum DNA damage at $48 \mathrm{hrs}$ (Figure 7). The data also indicates that while the DNA damages caused by the MFI-100 were short termed reducing at $48 \mathrm{hrs}$ (Figure 7), genotoxicity caused by the MFI-50 nanoparticles in the A549 cells was observed to besustained longer (48 hrs), indicating the possibility of variation in pathways / cell organelles involved in the ROS generation and therefore the dissimilarity in the time for the oxidative intermediates to reach and react with the genomic DNA. The data also indicated 
that at the time point of maximum DNA damage in the A549 cells exposed to the MFI-50 and MFI-100 nanoparticles, a concentration dependent increase in the level of DNA fragmentation occurs up to the measured dosage of $50 \mu \mathrm{g} / \mathrm{ml}$ (Figure 7).

A comparison between the generation of intracellular ROS (Figure $4 \mathrm{~A}, \mathrm{~B}$ ), $\Delta \Psi \mathrm{m}$ (Figure $5 \mathrm{~A}$, B) and the resulting genotoxicity (Figure 7) in the A549 cells following exposure to the MFI50 and MFI-100 nanoparticles indicated an inter-relationship between the three factors. Maximum DNA fragmentation in the A549 cells exposed to both the MFI-50 and MFI-100 nanoparticles was observed to occur post-highest generation of ROS and $\Delta \Psi \mathrm{m}$ alteration at $12 \mathrm{hrs}$ exposure.

The study also indicated that while ROS generation subsided in the A549 cells and the cells recovered from oxidative stress following exposure to both the MFI-50 and MFI-100 nanoparticles at the point of $24 \mathrm{hrs}$, genotoxicity (DNA fragmentation) continued to occur and increase post-oxidative stress through possible interaction between the genomic DNA strands and ROS oxidation intermediates. 


\section{Discussion and conclusion}

This study explored the varying biological response of the human lung alveolar epithelial (A549) cells to exposure to zeolite nanoparticles (MFI-50 and MFI-100, $50 \mathrm{~nm}$ and $100 \mathrm{~nm}$ in diameter, respectively) in terms of cell viability, oxidative stress and mitochondrial membrane potential $(\Delta \Psi \mathrm{m})$ variation and genotoxicity under in vitro conditions.

The zeolite nanoparticles (MFI-50 and MFI-100) indicated that while they are well dispersed in pure water, suspensions in the cell culture medium resulted in adsorption of biomolecules and ions on their native surface, causing the formation of a surface corona and a reduction of their zeta potential. The resulting loss of zeta potential caused the agglomeration of the nanoparticles leading to precipitation out of the colloidal suspension as sediment to bottom of the cell culture flask. The phenomenon of adsorption of protein on the surface of the nanoparticles (Gray, 2004; Lynch et al., 2006) leading to their aggregation, or agglomeration is well reported (Borm et al., 2006; Lynch et al., 2007).Studies using gold nanoparticles suggested that varying rate of sedimentation following agglomeration of the nanoparticles having particle size distribution beyond the threshold limit of $50 \mathrm{~nm}$, areimportant factors for determining the type of biological response in the cellular system following their uptake(Cho et al., 2011; Lison and Huaux, 2011). In our study, we observed that the majority of these large agglomerates of nanoparticles, behaving as large particles, came in contact with the cell surface possibly along with nanoparticles smaller than the resolution of a light microscope $(200 \mathrm{~nm})$.

The study showed that the zeolite nanoparticles $(50 \mathrm{~nm}$ and $100 \mathrm{~nm})$ at the used concentrations were non-cytotoxic to the A549 cells at the used concentrations. The observed non-cytotoxicity of the nanoparticles at test concentrations up to $100 \mu \mathrm{g} / \mathrm{ml}$ qualified them as $\geq$ Category 3 toxicity substance, as per the published OECD 423 guidelines (Byrne et al., 2010; OECD, 2001). The absence of catalytic surface activity of zeolite nanoparticles supported the intracellular origin of reactive oxygen species (ROS) in the A549 cells following exposure to the nanoparticles. Intracellular ROS, under normal physiological conditions, are major signalling molecules and are regulated through antioxidants (Valko et al., 2007). Under stress conditions, the extensive network of cellular antioxidants, divided into primary (glutathione peroxidase, superoxide dismutase, catalase and thioredoxinreductase) and secondary (reduced glutathione) defense mechanisms, play a major role (Stahl et. al., 1998) in converting the ROS into non-reactive molecules.However, overexpression of ROS results in reduced antioxidant protection, breakdown of functional biomolecules into unusable by-products and a cascade of events causing oxidative stress, genomic instability and apoptosis, or, unregulated cellular growth stimulation (cancer) (Halliwell and Whiteman, 2004). In our study, the absence of any relationship between the non-cytotoxic behavior of the Zeolite nanoparticles,although causing intracellular oxidative stress in the exposed A549 cells, indicated the possibility that the intracellular antioxidant system is capable of regulating the level of ROS below the minimum threshold limits required for cellular injury and death. 
While our study demonstrated a close correlation between the generation of intracellular ROS and elevated levels of mitochondrial membrane potential $(\Delta \Psi \mathrm{m})$, the non-linear relationship between the two indicates the possible presence of other modes of intracellular ROS generation. Mukherjee et al. (Mukherjee et al., 2010), working with polymeric dendrimers, have previously demonstrated that intracellular ROS can be generated within secondary endosomes and lysosomal compartments following the uptake of polymeric nanoparticles. Therefore, the presence of a similar mechanism cannot be ruled out. Cellular organelles such as endosomes, lysosomes and Golgi apparatus are well known for their capability to generate ROS in various metabolic and food processing activities (Andreyev et al., 2005; Jiang et al., 2011; Kurz et al., 2010; Mukherjee et al., 2010). The role of elevated $\Delta \Psi \mathrm{m}$ and increased ROS generation following exposure of the A549 cells to zeolite nanoparticles (50 nm and 100 $\mathrm{nm}$ ) can be related to the previous studies done by O'Rouke(O'Rourke, 2007) and Nicholls (Nicholls, 1977) who have reported that a high mitochondrial membrane potential indicates an increase in the proton motive force, thereby increasing the rate of oxidative phosphorylation, $\mathrm{K}^{+}$ionophore activation and ROS generation.

Oxidation of DNA bases as a result of oxidative stress (elevated ROS levels) following exposure to geno-toxicants leads to DNA fragmentation, which is a well-studied indicator of long term damage incurred by an organism (Collins et al., 1996; Moller, 2005). Previous in vitro studies, performed on mammalian cells lines, have demonstrated increased DNA fragmentation resulting from oxidative stress following exposure to different metallic and polymeric nanoparticles (Bhattacharya et al., 2009; Mukherjee et al., 2010). In the present study, the silica based zeolite with MFI type structure with $50 \mathrm{~nm}$ and $100 \mathrm{~nm}$ nanoparticles were found to induce a concentration dependent increase in genotoxic effect in the exposed A549 cells. However, the rate at which maximum genomic damage occurs in the A549 cells tended to be different for both the nanoparticles, with the MFI nanoparticle with $100 \mathrm{~nm}$ inducing faster DNA damage as compared to the smaller $(50 \mathrm{~nm})$ nanoparticles. It was further noticed that, while the DNA damage caused by the MFI-100 nanoparticles recovered over time, the damage caused by MFI-50 nanoparticles accumulated over time and was not found to be decreased at the maximum time-point studied. However, long term damage such as point mutations as a result of DNA repair mistakes in the cells exposed to the larger 100 $\mathrm{nm}$ nanoparticles cannot be ruled out.

The study thus demonstrated that non-cytotoxic zeolite nanoparticles (50 nm and $100 \mathrm{~nm}$ ) were capable of inducing DNA damage through intracellular generation of ROS and modified metabolic activity as shown by $\Delta \Psi \mathrm{m}$. While, the cellular damage induced by both zeolite nanoparticles was at high dosage not environmentally relevant, the study model demonstrated cellular damages occurring from long term accumulation of biopersistent nanoparticles.

The conclusion drawn from this study shows that that the pure silica MFI-type zeolite with 50 $\mathrm{nm}$ and $100 \mathrm{~nm}$ nanoparticles are relatively non-reactive and -cytotoxic to the human alveolar cells. The observed oxidative stress, heightened mitochondrial activity and genotoxic damages occur at environmentally non-relevant high dosage levels. However, their potential to cause damage makes them candidates, like other metal oxide based nanoparticles, to cause 
lung diseases following long term bioaccumulation and biodistribution. Accumulation of these biopersistent nanoparticles inside human lung following inhalation over long periods of time can cause long term health effects and therefore care should be taken in handling of the nanoparticles. Further studies are in progress to provide a better understanding of the role of mitochondrial and other cell organelles in causing oxidative stress and possible relation to observed genotoxicity. 


\section{Acknowledgement}

This work was conducted under the framework of the INSPIRE programme, funded by the Irish Government's Programme for Research in Third Level Institutions, Cycle 4, National Development Plan 2007-2013, supported by the European Union Structural Fund. 


\section{Legends}

Table 1:Physicochemical characterization of MFI-50 and MFI-100 nanoparticles in dry and suspended (water and RPMI-1640 cell culture media with 5\% foetal bovine serum) condition at ambient temperature $\left(25^{\circ} \mathrm{C}\right)$.

Figure 1. Scanning electron microscopic (SEM) images of (a) MFI-50 and (b) MFI-100 nanocrystals.

Figure 2: Surface catalytic activity measurement of MFI-50 and MFI-100 nanoparticles suspended in $10 \mathrm{mM}$ concentration of 4-Morpholinepropanesulfonic acid sodium salt (Mops) buffer and $5 \mathrm{mM}$ concentration of hydrogen peroxide $\left(\mathrm{H}_{2} \mathrm{O}_{2}\right)$ using Europium(III)Tetracycline dye. The measurements were taken at different time points of 45, 60 and 75 mins. Ferrous Sulphate $\left(\mathrm{FeSO}_{4}\right)$ was used as a positive control and $10 \mathrm{mM}$ Mops buffer with $5 \mathrm{mM} \mathrm{H}_{2} \mathrm{O}_{2}$ with no nanoparticles was used as a negative control.

Figure 3: Cellular proliferative capacity of the A549 cells exposed to the MFI-50 and MFI100 nanoparticles for the measured concentrations of $0.001-100 \mu \mathrm{g} / \mathrm{ml}$ and the exposure time points of 24 and $48 \mathrm{hr}$ using alamar blue assay.

Figure 4: Intracellular oxidative stress measured using fluorescent 5-(and-6)-chloromethyl-2, 7-dichlorodihydrofluorescein diacetate acetyl ester dye in A549 cells exposed to (A) MFI-50, and (B) MFI-100 nanoparticles for the time periods of 2, 4, 6, 12 and 24 hours (hr).Change in the intracellular levels of free radicals is depicted as fluorescence percentage relative to the negative control set at zero ' 0 ' and hence is at the baseline level ( $\mathrm{x}$ axis) and not visible. $\mathrm{P}$ Values: $<0.001$ - ***; $<0.01$ - **; $<0.05$ - *.Figures ' $\mathrm{C}$ ' and ' $\mathrm{D}$ ' represent comparative analysis of intracellular ROS generated at 4 and $12 \mathrm{hrs}$, respectively in the A549 cells following exposure to the MFI-50 and MFI-100 nanoparticles.

Figure 5: Mitochondrial membrane potential of the A549 cells exposed to (A) MFI-50, and (B) MFI-100 nanoparticles for the time period of 2, 4, 6, 12 and 24 hours (hr) using fluorescent Rhodamine-123 dye. Change in the mitochondrial membrane potential is depicted as fluorescence percentage relative to the negative control set at zero ' 0 ' and hence is at the baseline level (x axis) and not visible. P Values: $<0.001$ - ***; $<0.01-* * ;<0.05$ - *.

Figure 6: Comparative analysis of intracellular ROS generation and mitochondrial membrane potential of the A549 cells exposed to MFI-50 and MFI-100 nanoparticles for (A) 4 and (B) 12 hrs.

Figure 7: DNA damage in the A549 cells exposed to MFI-50 and MFI-100 nanoparticles for the time durations of 12, 24 and 48 hours (hrs) measured using alkaline comet assay and Olive tail moment parameter. The negative control was set at zero ' 0 ' and hence is at the baseline level (x axis) and not visible. P Values: $<0.001$ - ***; $<0.01-* * ;<0.05$ - *. 


\section{References}

Andreyev, A.Y., Kushnareva, Y.E., Starkov, A.A., 2005. Mitochondrial metabolism of reactive oxygen species. Biochemistry 70, 200-214.

AshaRani, P.V., Low Kah Mun, G., Hande, M.P., Valiyaveettil, S., 2009. Cytotoxicity and genotoxicity of silver nanoparticles in human cells. ACS Nano 3, 279-290.

Bedi, R.S., Beving, D.E., Zanello, L.P., Yan, Y., 2009. Biocompatibility of corrosion-resistant zeolite coatings for titanium alloy biomedical implants. Acta Biomater 5, 3265-3271.

Bein, T., Mintova, S., Bekkum, J.Ä.a.H.v., 2005. Advanced applications of zeolites.Studies in Surface Science and Catalysis, vol. Volume 157. Elsevier, pp. 263-288.

Bhattacharya, K., Davoren, M., Boertz, J., Schins, R.P., Hoffmann, E., Dopp, E., 2009. Titanium dioxide nanoparticles induce oxidative stress and DNA-adduct formation but not DNA-breakage in human lung cells. Part FibreToxicol 6, 17.

Bhattacharya, K., Hoffmann, E., Schins, R.F., Boertz, J., Prantl, E.M., Alink, G.M., Byrne, H.J., Kuhlbusch, T.A., Rahman, Q., Wiggers, H., Schulz, C., Dopp, E., 2012. Comparison of microand nanoscale $\mathrm{Fe}+3$-containing (Hematite) particles for their toxicological properties in human lung cells in vitro. ToxicolSci 126, 173-182.

Borm, P.J., Robbins, D., Haubold, S., Kuhlbusch, T., Fissan, H., Donaldson, K., Schins, R., Stone, V., Kreyling, W., Lademann, J., Krutmann, J., Warheit, D., Oberdorster, E., 2006. The potential risks of nanomaterials: a review carried out for ECETOC. Part FibreToxicol 3, 11.

Brown, T., 2009.Silica exposure, smoking, silicosis and lung cancer--complex interactions.Occup Med (Lond) 59, 89-95.

Brunauer, S., Emmett, P.H., Teller, E., 1938. Adsorption of Gases in Multimolecular Layers. J Am ChemSoc 60, 309-319.

Brunner, T.J., Wick, P., Manser, P., Spohn, P., Grass, R.N., Limbach, L.K., Bruinink, A., Stark, W.J., 2006. In vitro cytotoxicity of oxide nanoparticles: comparison to asbestos, silica, and the effect of particle solubility. Environ SciTechnol 40, 4374-4381.

Burtea, C., Laurent, S., Vander Elst, L., Muller, R.N., 2008.Contrast agents: magnetic resonance. HandbExpPharmacol, 135-165.

Byrne, H.J., Lynch, I., de Jong, W.H., Kreyling, W.G., Loft, S., Park, M.V.D.Z., Riediker, M., Warheit, D., 2010.Protocols for assessment of biological hazards of engineered nanomaterials. In: Bouwmeester, H., Cassee, F., Dusinska, M. (Eds.) Deliverable 17 under the European Commission's Seventh Framework Programme, NMP4-CA-2008-218539, Grant Agreement 218539 for Project NanoImpactNetNanoImpactNet.

Chang, J.S., Chang, K.L., Hwang, D.F., Kong, Z.L., 2007. In vitro cytotoxicitiy of silica nanoparticles at high concentrations strongly depends on the metabolic activity type of the cell line. Environ SciTechnol 41, 2064-2068.

Cho, E.C., Zhang, Q., Xia, Y., 2011. The effect of sedimentation and diffusion on cellular uptake of gold nanoparticles. Nat Nanotechnol 6, 385-391. 
Collins, A.R., Dusinska, M., Gedik, C.M., Stetina, R., 1996.Oxidative damage to DNA: do we have a reliable biomarker? Environ Health Perspect 104 Suppl 3, 465-469.

Colvin, V.L., 2003. The potential environmental impact of engineered nanomaterials. Nat Biotechnol 21, 1166-1170.

Comet, A., Forum, 2011. http://www.cometassayindia.org/definitions.htm. vol. 2011, Indian Institute of Toxicological Research, India, p. COmet Assay Definitions.

Davoren, M., Herzog, E., Casey, A., Cottineau, B., Chambers, G., Byrne, H.J., Lyng, F.M., 2007.In vitro toxicity evaluation of single walled carbon nanotubes on human A549 lung cells.Toxicolln Vitro 21, 438-448.

De Jong, W.H., Borm, P.J., 2008. Drug delivery and nanoparticles:applications and hazards. Int J Nanomedicine 3, 133-149.

Dehaen, G., Absillis, G., Driesen, K., Binnemans, K., Parac-Vogt, T.N., 2009. (Tetracycline)europium(III) Complex as Luminescent Probe for Hydrogen Peroxide Detection. Helvetica ChimicaActa 92, 2387-2397.

Donaldson, K., Poland, C.A., Schins, R.P., 2010. Possible genotoxic mechanisms of nanoparticles: criteria for improved test strategies. Nanotoxicology 4, 414-420.

Elias, Z., Poirot, O., Daniere, M.C., Terzetti, F., Marande, A.M., Dzwigaj, S., Pezerat, H., Fenoglio, I., Fubini, B., 2000. Cytotoxic and transforming effects of silica particles with different surface properties in Syrian hamster embryo (SHE) cells. ToxicolIn Vitro 14, 409-422.

Furlong, I.J., Lopez Mediavilla, C., Ascaso, R., Lopez Rivas, A., Collins, M.K., 1998. Induction of apoptosis by valinomycin: mitochondrial permeability transition causes intracellular acidification. Cell death and differentiation 5, 214-221.

Gray, J.J., 2004. The interaction of proteins with solid surfaces.CurrOpinStructBiol 14, 110-115.

Hackenberg, S., Friehs, G., Froelich, K., Ginzkey, C., Koehler, C., Scherzed, A., Burghartz, M., Hagen, R., Kleinsasser, N., 2009. Intracellular distribution, geno- and cytotoxic effects of nanosized titanium dioxide particles in the anatase crystal phase on human nasal mucosa cells. ToxicolLett 195, 9-14.

Halliwell, B., Whiteman, M., 2004. Measuring reactive species and oxidative damage in vivo and in cell culture: how should you do it and what do the results mean? British journal of pharmacology 142, 231-255.

Huang, H.C., Chang, P.Y., Chang, K., Chen, C.Y., Lin, C.W., Chen, J.H., Mou, C.Y., Chang, Z.F., Chang, F.H., 2009. Formulation of novel lipid-coated magnetic nanoparticles as the probe for in vivo imaging. J Biomed Sci 16, 86.

Jacobsen, N.R., Moller, P., Jensen, K.A., Vogel, U., Ladefoged, O., Loft, S., Wallin, H., 2009.Lung inflammation and genotoxicity following pulmonary exposure to nanoparticles in ApoE-/- mice.Part FibreToxicol 6, 2.

Jiang, Z., Hu, Z., Zeng, L., Lu, W., Zhang, H., Li, T., Xiao, H., 2011. The role of the Golgi apparatus in oxidative stress: is this organelle less significant than mitochondria? Free RadicBiol Med 50, 907-917. 
Jovanovic, A.V., Flint, J.A., Varshney, M., Morey, T.E., Dennis, D.M., Duran, R.S., 2006. Surface modification of silica core-shell nanocapsules: biomedical implications. Biomacromolecules 7, 945-949.

Karlsson, H.L., Cronholm, P., Gustafsson, J., Moller, L., 2008. Copper oxide nanoparticles are highly toxic: a comparison between metal oxide nanoparticles and carbon nanotubes. Chem Res Toxicol 21, 1726-1732.

Karlsson, H.L., Gustafsson, J., Cronholm, P., Moller, L., 2009. Size-dependent toxicity of metal oxide particles--a comparison between nano- and micrometer size.Toxicol Lett 188, 112-118.

Kurz, T., Eaton, J.W., Brunk, U.T., 2010. Redox activity within the lysosomal compartment: implications for aging and apoptosis. Antioxid Redox Signal 13, 511-523.

Leite, E., Babeva, T., Ng, E.P., Toal, V., Mintova, S., Naydenova, I., 2010. Optical Properties of Photopolymer Layers Doped with AluminophosphateNanocrystals. The Journal of Physical Chemistry C 114, 16767-16775.

Liao, H., Nehl, C.L., Hafner, J.H., 2006. Biomedical applications of plasmon resonant metal nanoparticles.Nanomedicine (Lond) 1, 201-208.

Lison, D., Huaux, F., 2011. In vitro studies: Ups and downs of cellular uptake. Nat Nanotechnol 6, 332-333.

Lynch, I., Cedervall, T., Lundqvist, M., Cabaleiro-Lago, C., Linse, S., Dawson, K.A., 2007. The nanoparticle-protein complex as a biological entity; a complex fluids and surface science challenge for the 21st century. Adv Colloid Interface Sci 134-135, 167-174.

Lynch, I., Dawson, K.A., Linse, S., 2006. Detecting cryptic epitopes created by nanoparticles. Sci STKE 2006, pe14.

Majano, G., Mintova, S., Bein, T., Klapötke, T.M., 2006. High-Density Energetic Material Hosted in Pure Silica MFI-Type Zeolite Nanocrystals. Advanced Materials 18, 2440-2443.

McLennan, H.R., DegliEsposti, M., 2000.The contribution of mitochondrial respiratory complexes to the production of reactive oxygen species.Journal of bioenergetics and biomembranes 32, 153-162.

Mihailova, B., Mintova, S., Karaghiosoff, K., Metzger, T., Bein, T., 2005. Nondestructive identification of colloidal molecular sieves stabilized in water. J PhysChem B 109, 17060-17065.

Mintova, S., 2003.Nanosized molecular sieves. Collection of Czechoslovak Chemical Communications 68, 2032-2054.

Mintova, S., Bein, T., 2001.Microporous Films Prepared by Spin-Coating Stable Colloidal Suspensions of Zeolites. Advanced Materials 13, 1880-1883.

Mintova, S., Olson, N.H., Bein, T., 1999a. Electron Microscopy Reveals the Nucleation Mechanism of Zeolite Y from Precursor Colloids. AngewChemInt Ed Engl 38, 3201-3204.

Mintova, S., Olson, N.H., Senker, J., Bein, T., 2002.Mechanism of the transformation of silica precursor solutions into Si-MFI zeolite.AngewChemInt Ed Engl 41, 2558-2561.

Mintova, S., Olson, N.H., Valtchev, V., Bein, T., 1999b.Mechanism of Zeolite A Nanocrystal Growth from Colloids at Room Temperature. Science 283, 958-960. 
Mintova, S., Valtchev, V., 2002. Effect of the silica source on the formation of nanosized silicalite-1: an in situ dynamic light scattering study. Microporous and Mesoporous Materials 55, 171-179.

Moller, P., 2005.Genotoxicity of environmental agents assessed by the alkaline comet assay. Basic ClinPharmacolToxicol 96 Suppl 1, 1-42.

Mukherjee, S.P., Lyng, F.M., Garcia, A., Davoren, M., Byrne, H.J., 2010. Mechanistic studies of in vitro cytotoxicity of poly(amidoamine) dendrimers in mammalian cells. ToxicolApplPharmacol 248, 259-268.

Ng, E.P., Chateigner, D., Bein, T., Valtchev, V., Mintova, S., 2012.Capturing ultrasmall EMT zeolite from template-free systems. Science 335, 70-73.

Nicholls, D.G., 1977. The effective proton conductance of the inner membrane of mitochondria from brown adipose tissue.Dependency on proton electrochemical potential gradient.European journal of biochemistry / FEBS 77, 349-356.

O'Rourke, B., 2007. Mitochondrialionchannels. Annu Rev Physiol 69, 19-49.

Oberdorster, G., Oberdorster, E., Oberdorster, J., 2005. Nanotoxicology: an emerging discipline evolving from studies of ultrafine particles. Environ Health Perspect 113, 823-839.

OECD, 2001. Guideline (423) for Testing of Chemicals : Acute Oral Toxicity - Acute Toxic Class Method. Organisation for Economic Co-operation and Development

Salvati, A., Aberg, C., Dos Santos, T., Varela, J., Pinto, P., Lynch, I., Dawson, K.A., 2011. Experimental and theoretical comparison of intracellular import of polymeric nanoparticles and small molecules: toward models of uptake kinetics. Nanomedicine.

Simon-Deckers, A., Gouget, B., Mayne-L'hermite, M., Herlin-Boime, N., Reynaud, C., Carriere, M., 2008.In vitro investigation of oxide nanoparticle and carbon nanotube toxicity and intracellular accumulation in A549 human pneumocytes. Toxicology 253, 137-146.

Slowing, II, Wu, C.W., Vivero-Escoto, J.L., Lin, V.S., 2009. Mesoporous silica nanoparticles for reducing hemolytic activity towards mammalian red blood cells. Small 5, 57-62.

Smoluchowski, M., 1921.Handbuch der Electrizität und des Magnetismus (Graetz). Barth, Leipzig, Germany, pp. 366.

Stahl, W., Junghans, A., De Boer, B., Driomina, E.S., Brivida, K., Sies, H., 1998. Carotenoid mixtures protect multilamellar liposomes against oxidative damage: synergistic effects of lycopene and lutein. FEBS Lett. 427, 305-308.

Strano, M.S., Jin, H., 2008. Where is it heading? Single-particle tracking of single-walled carbon nanotubes. ACS Nano 2, 1749-1752.

Thannickal, V.J., Fanburg, B.L., 2000. Reactive oxygen species in cell signaling. Am J Physiol Lung Cell MolPhysiol 279, L1005-1028.

Valko, M., Leibfritz, D., Moncol, J., Cronin, M.T., Mazur, M., Telser, J., 2007.Free radicals and antioxidants in normal physiological functions and human disease.The international journal of biochemistry \& cell biology $39,44-84$.

Valtchev, V., Mintova, S., 2011. Nano-Microporous Materials: Hydrothermal Synthesis of Zeolites. Encyclopedia of Inorganic and Bioinorganic Chemistry.John Wiley \& Sons, Ltd. 
Worle-Knirsch, J.M., Kern, K., Schleh, C., Adelhelm, C., Feldmann, C., Krug, H.F., 2007. Nanoparticulate vanadium oxide potentiated vanadium toxicity in human lung cells. Environ SciTechnol 41, 331-336.

Yang, J., Gunn, J., Dave, S.R., Zhang, M., Wang, Y.A., Gao, X., 2008. Ultrasensitive detection and molecular imaging with magnetic nanoparticles. Analyst 133, 154-160.

Zhu, M.T., Feng, W.Y., Wang, B., Wang, T.C., Gu, Y.Q., Wang, M., Wang, Y., Ouyang, H., Zhao, Y.L., Chai, Z.F., 2008. Comparative study of pulmonary responses to nano- and submicron-sized ferric oxide in rats.Toxicology 247, 102-111. 
Table 1

\begin{tabular}{|c|c|c|c|c|c|c|}
\hline & \multicolumn{3}{|c|}{ MFI-50 nanoparticles } & \multicolumn{3}{|c|}{ MFI-100 nanoparticles } \\
\hline & $\begin{array}{c}\text { Zeta Potential } \\
\qquad(\mathbf{m V})\end{array}$ & $\begin{array}{c}\text { Particle Size } \\
\text { Distribution } \\
\text { [Number } \\
\text { Percentage] } \\
\text { (d.nm) }\end{array}$ & $\begin{array}{l}\text { Polydispersity } \\
\text { Index }\end{array}$ & $\begin{array}{c}\text { Zeta Potential } \\
(\mathrm{mV})\end{array}$ & $\begin{array}{c}\text { Particle Size } \\
\text { Distribution } \\
\text { [Number } \\
\text { Percentage] } \\
\text { (d.nm) }\end{array}$ & $\begin{array}{l}\text { Polydispersity } \\
\text { Index }\end{array}$ \\
\hline $\begin{array}{l}\text { Suspension in } \\
\text { double distilled } \\
\text { water }\end{array}$ & $-22.5 \pm 0.6$ & $41 \pm 3$ & $0.1 \pm 0.1$ & $-42.5 \pm 0.8$ & $77 \pm 3.0$ & $0.1 \pm 0.1$ \\
\hline $\begin{array}{l}\text { Suspension in } \\
\text { RPMI-1640 cell } \\
\text { culture media } \\
\text { with } 5 \% \text { Fetal } \\
\text { Bovine Serum }\end{array}$ & $-13.2 \pm 0.7$ & $79 \pm 10$ & $0.2 \pm 0.1$ & $-12.6 \pm 0.8$ & $127 \pm 32$ & $0.2 \pm 0.1$ \\
\hline
\end{tabular}




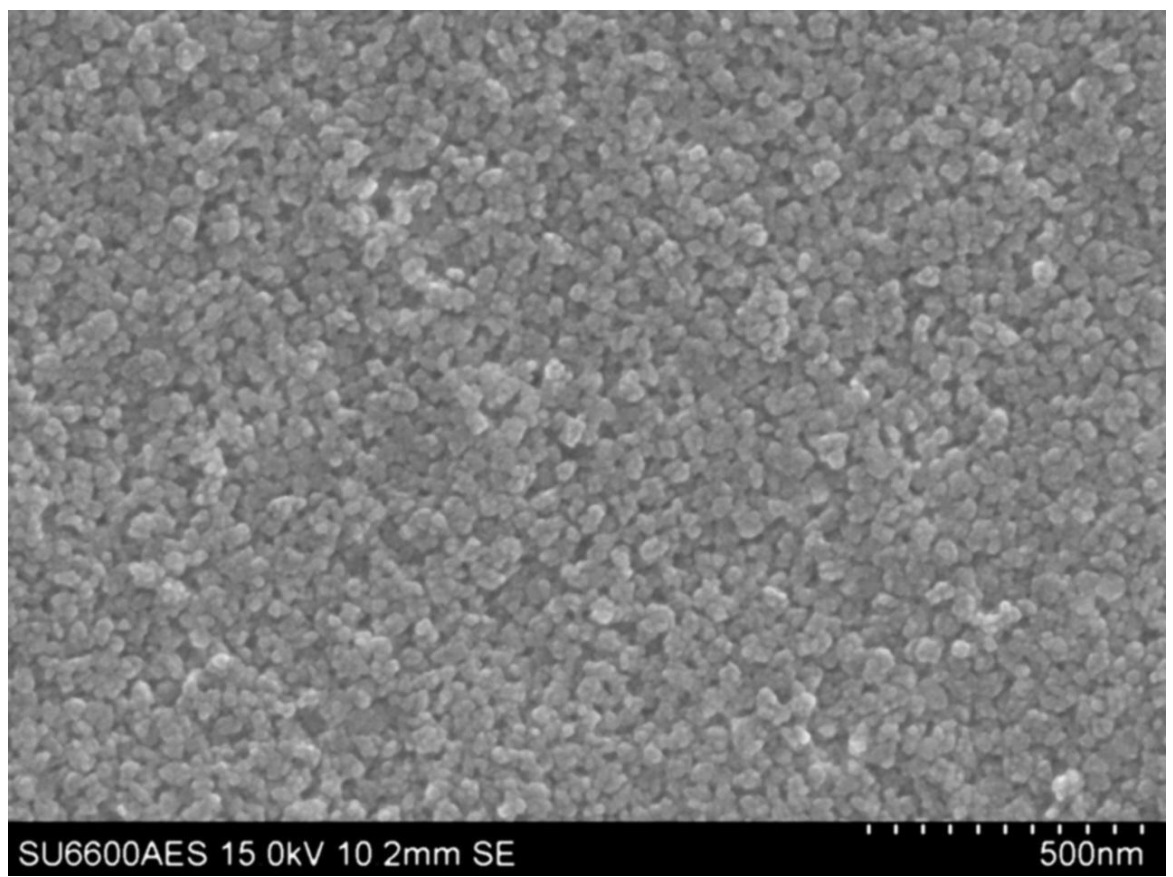

\section{Figure 1A}

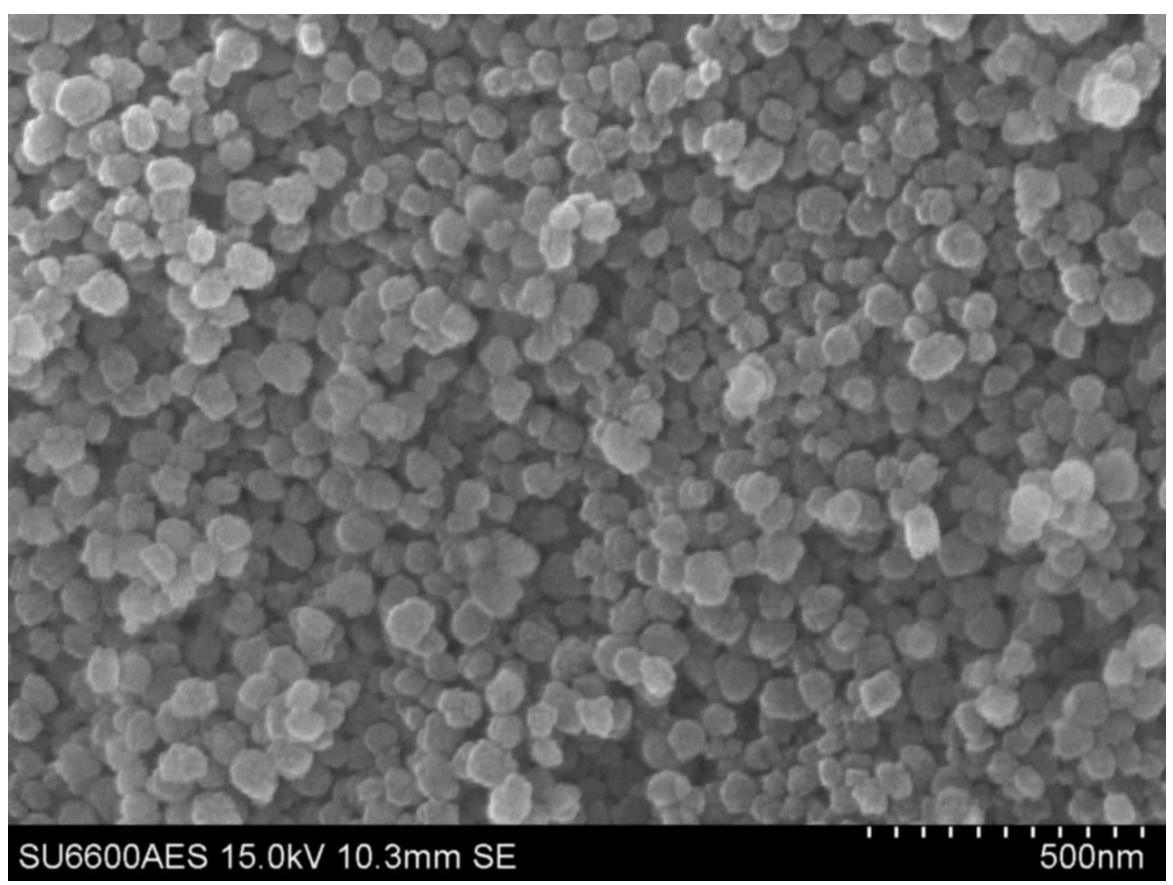

\section{Figure 1B}




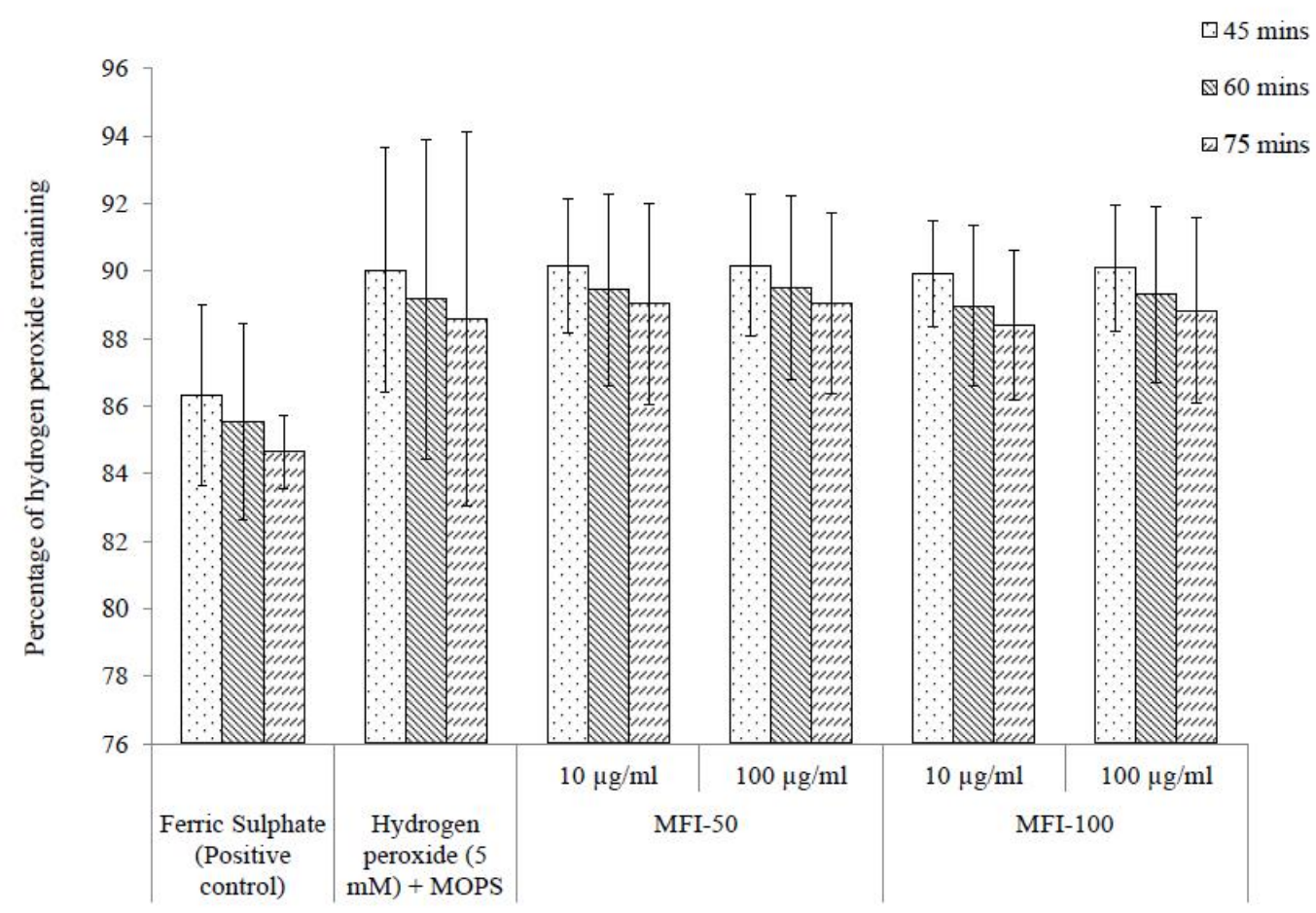

Figure 2

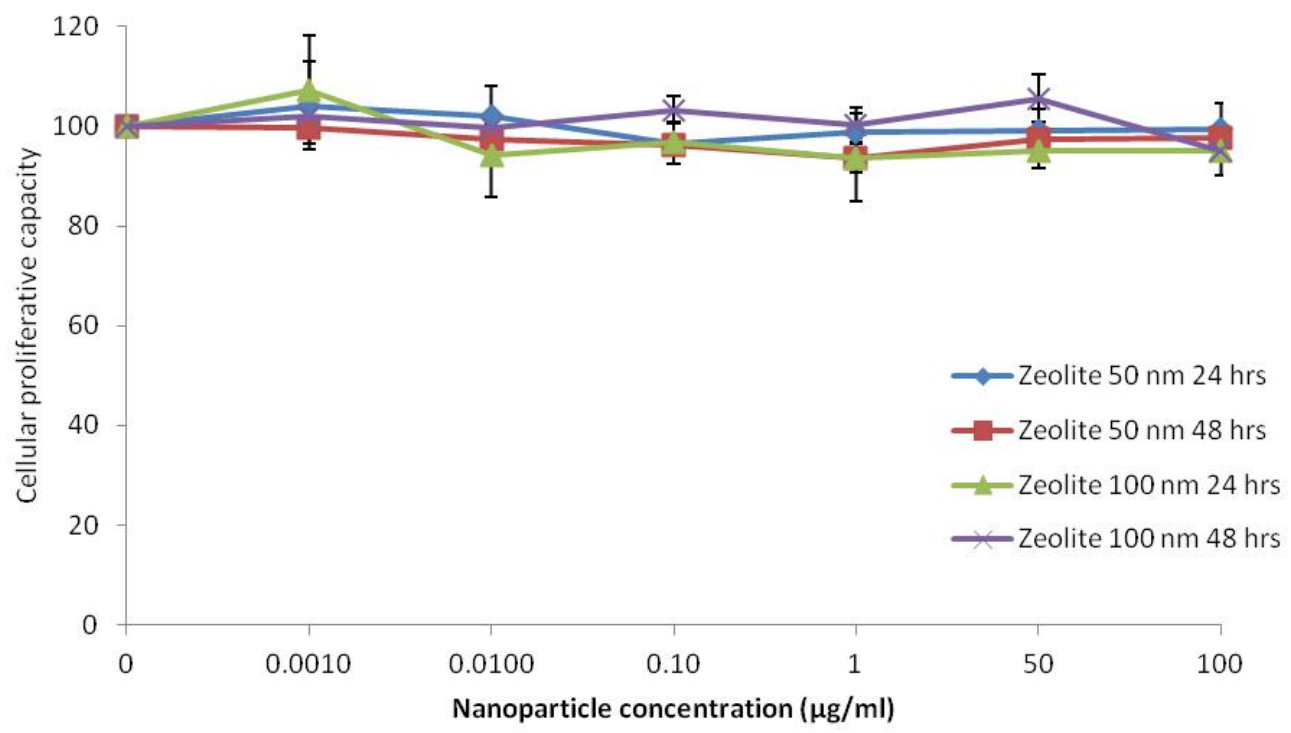

Figure 3 
Toxicology Letters, 215, 151-160 (2012)

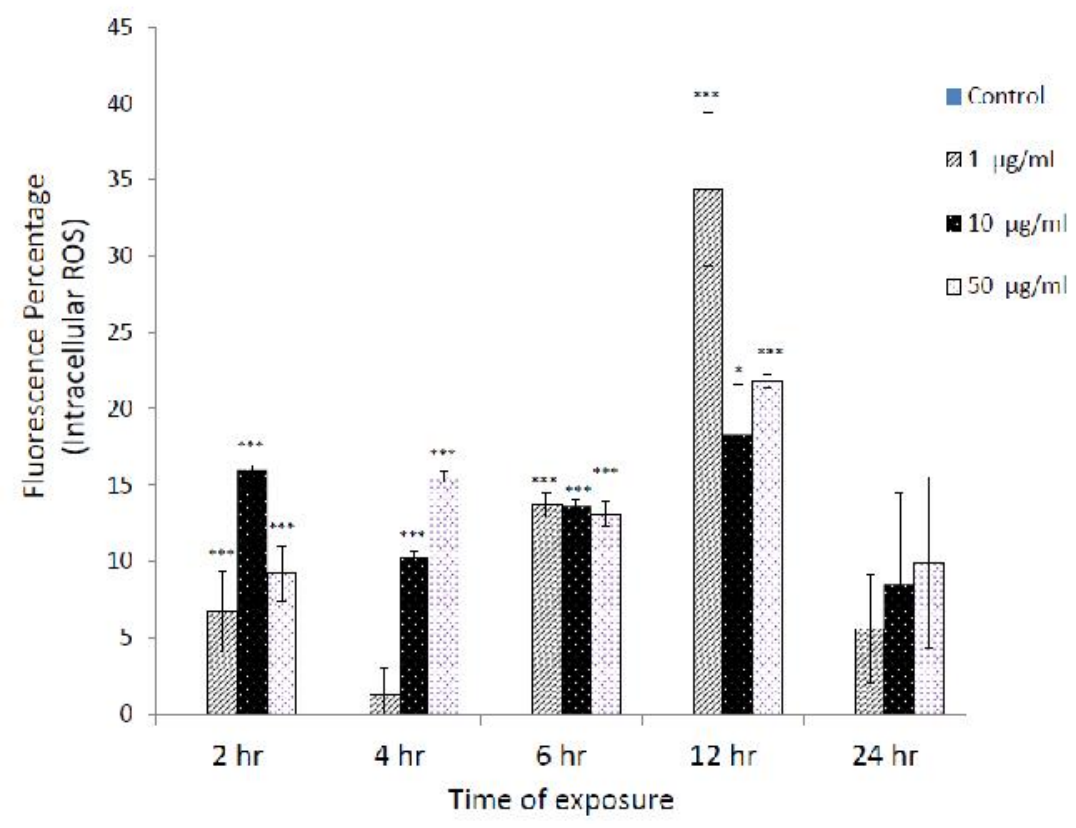

Figure 4A

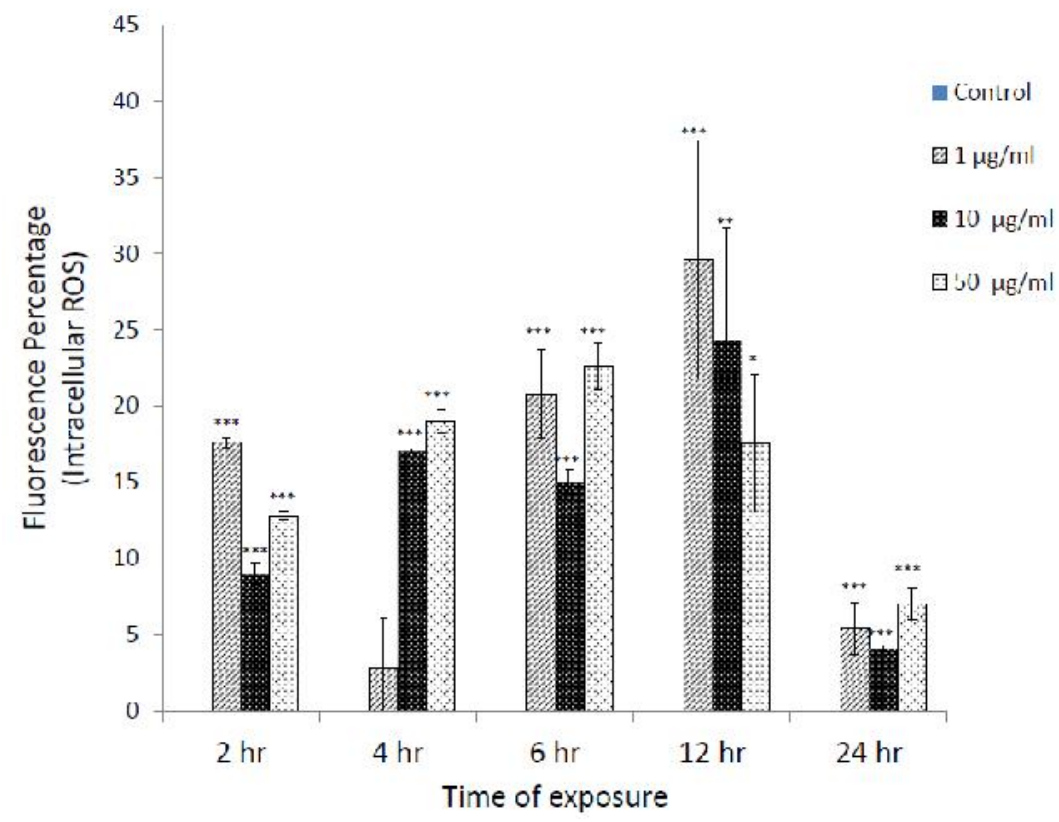

Figure 4B 


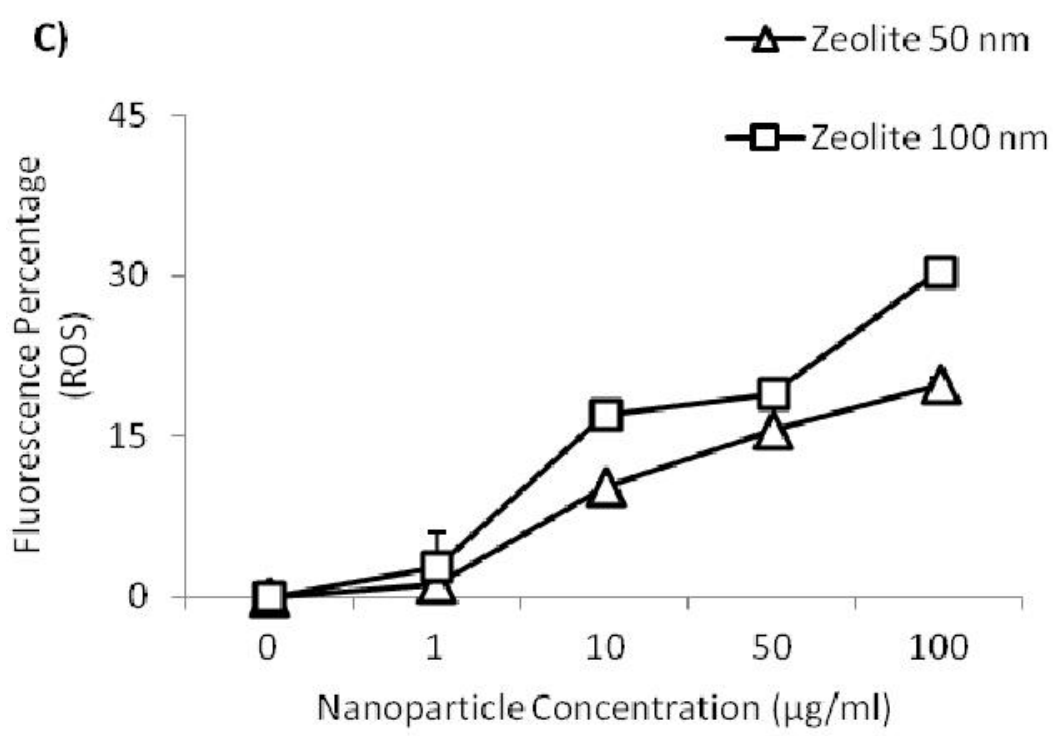

Figure 4C

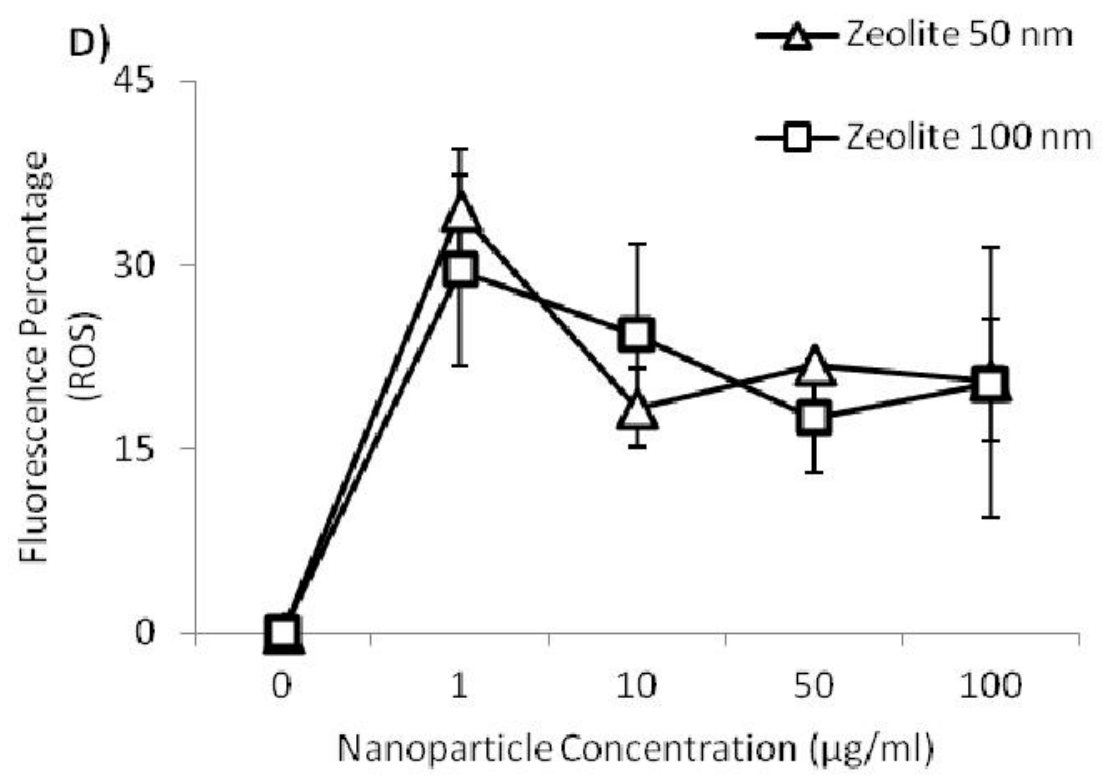

Figure 4D 
Toxicology Letters, 215, 151-160 (2012)

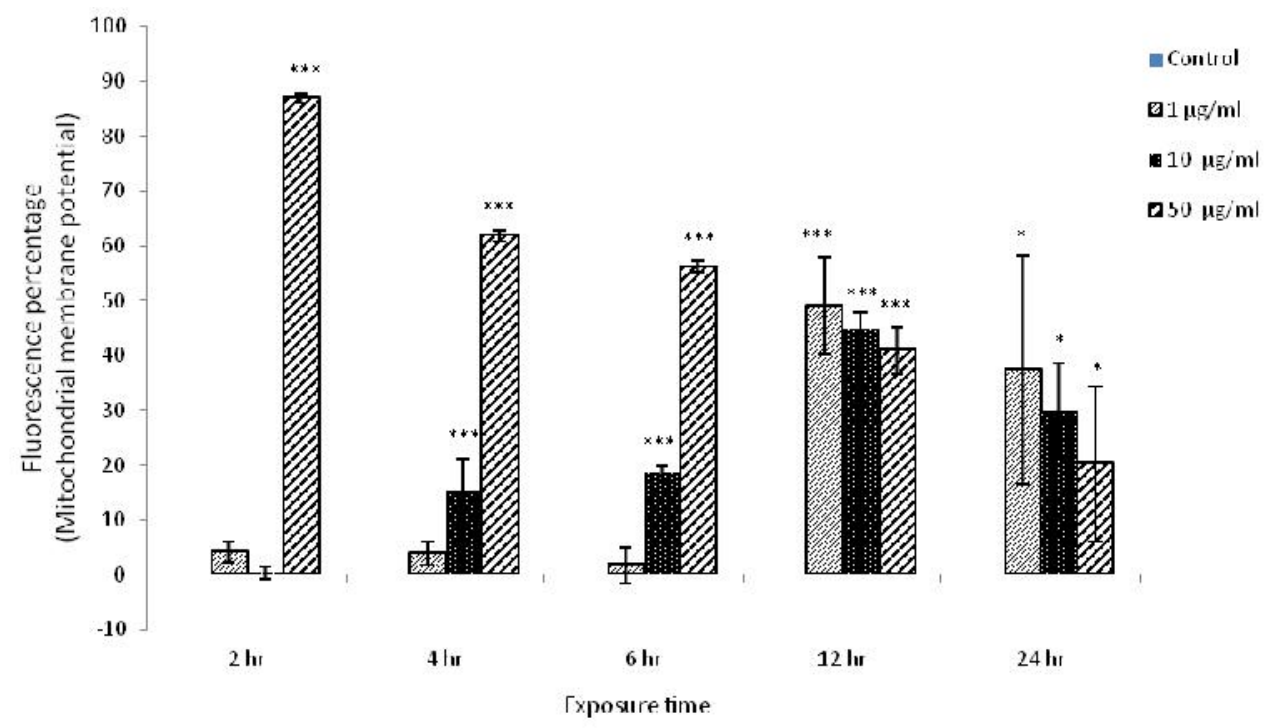

Figure 5A

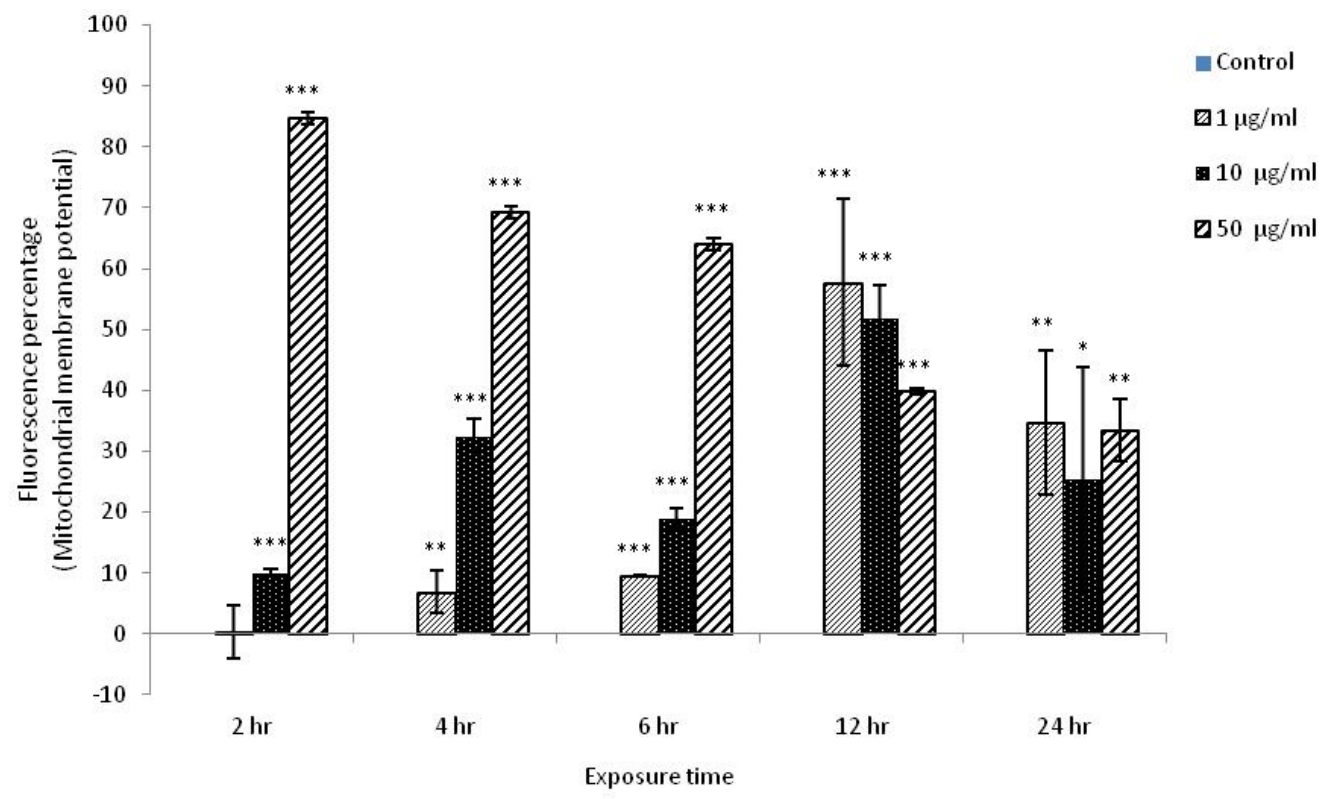

Figure 5B 


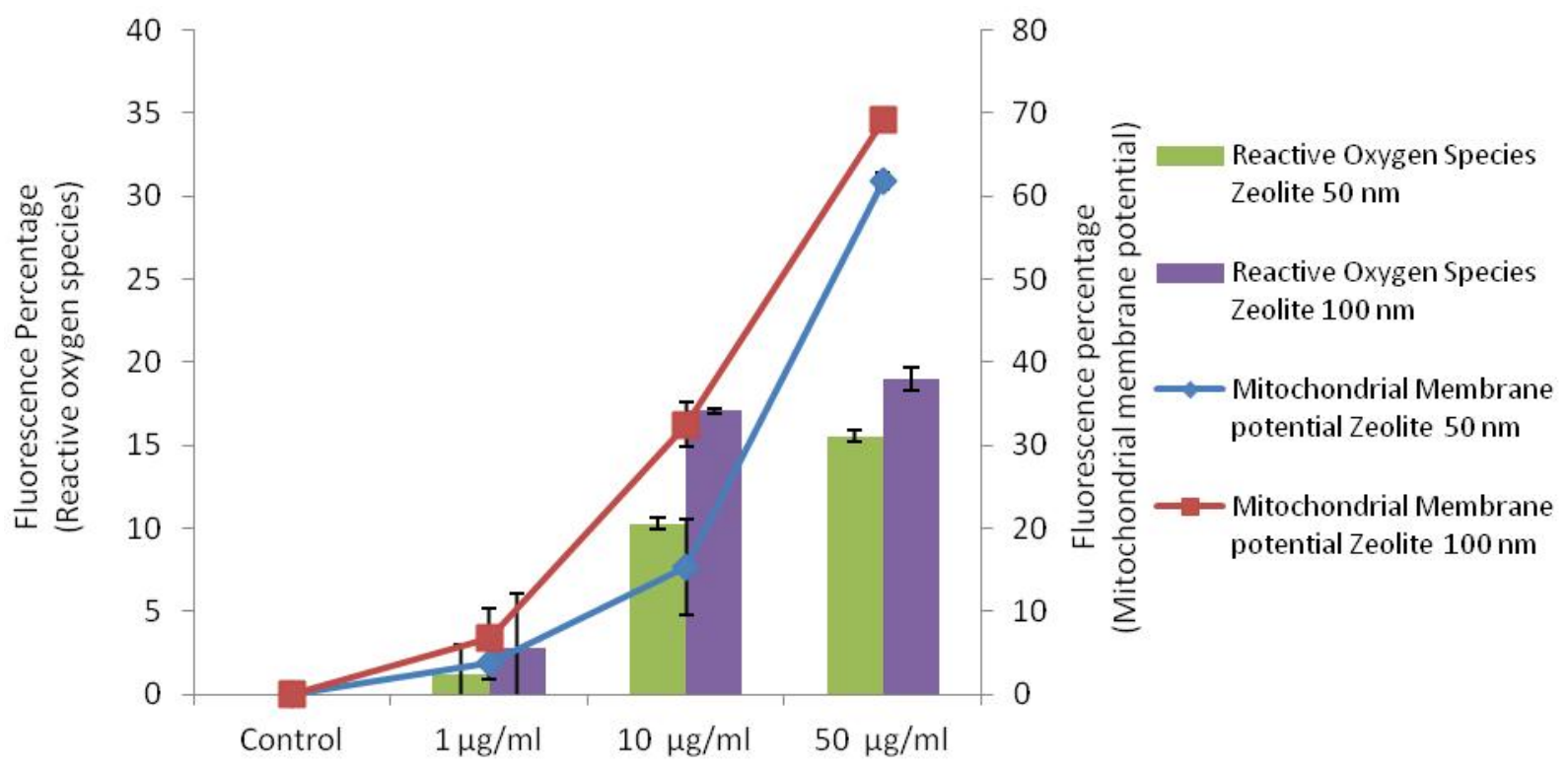

Figure 6A

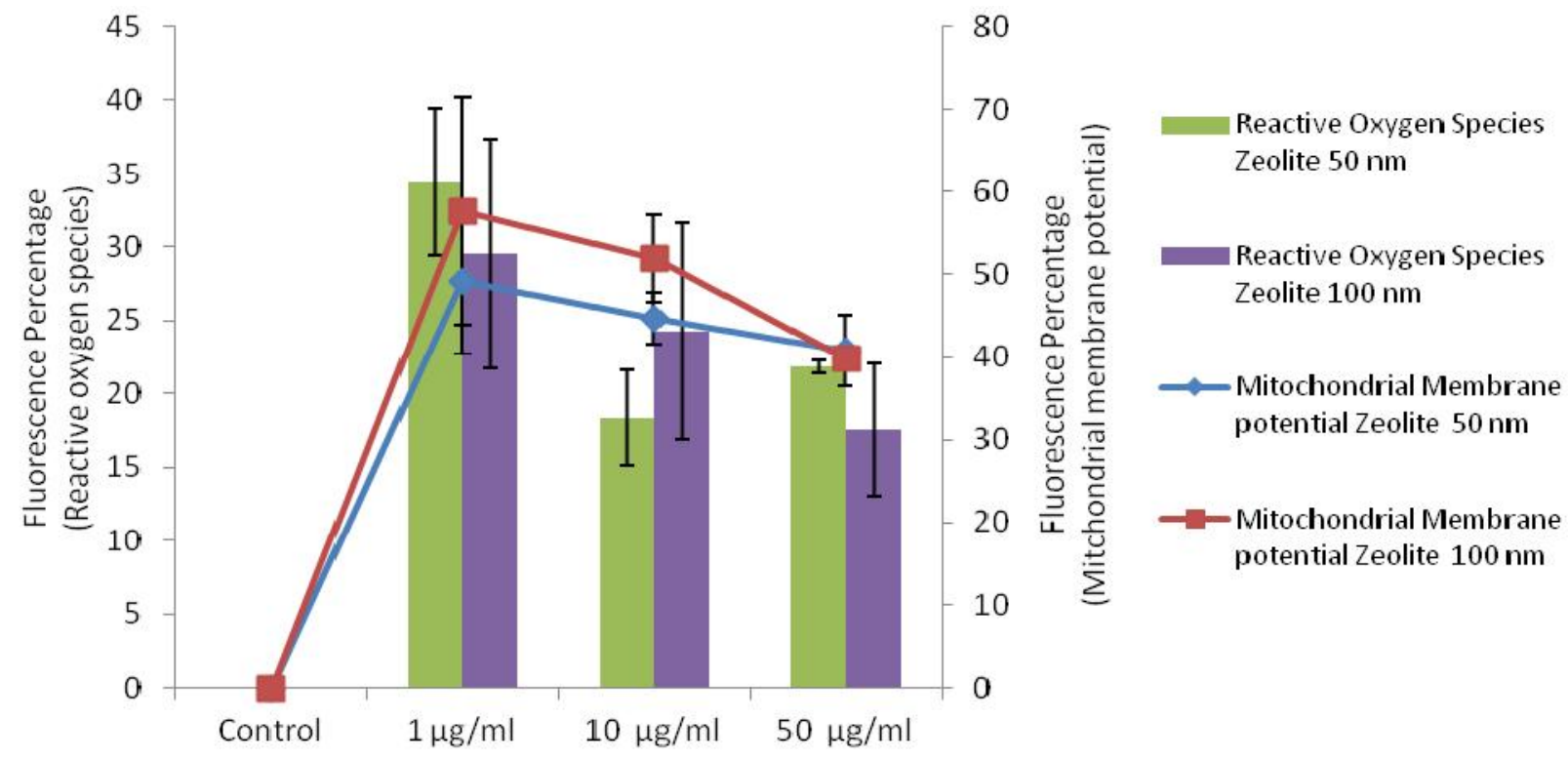

Figure 6B 
Toxicology Letters, 215, 151-160 (2012)

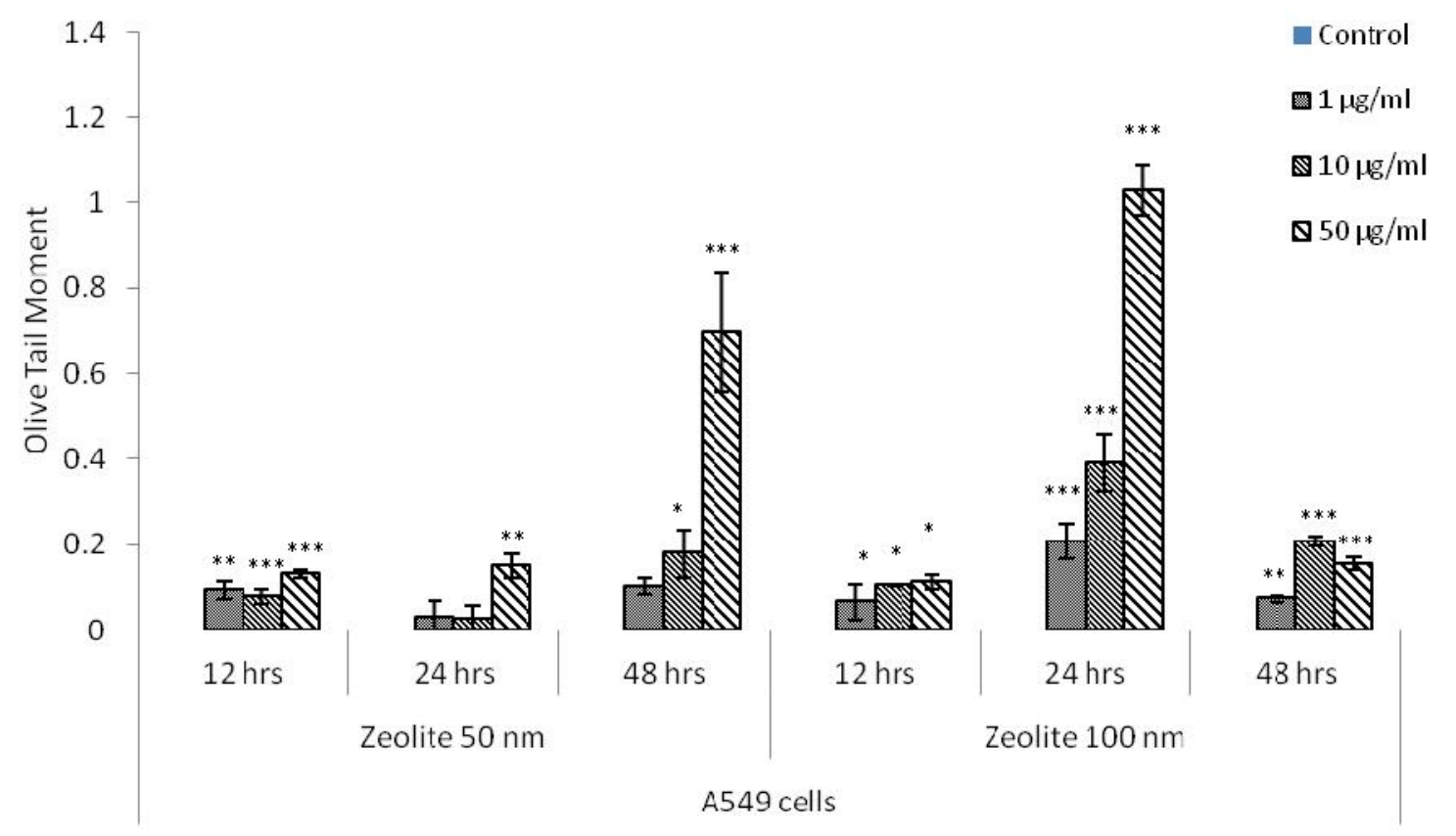

Figure 7 